\title{
Evaluation of Cleaning and Hygiene in Primary Schools According to The Opinions of The Students
}

\begin{tabular}{|c|c|}
\hline \multicolumn{2}{|c|}{$\begin{array}{l}{ }^{a} \text { Ministry of National Education, Afyonkarahisar/Turkey } \\
{ }^{b} \text { Dumlupinar University, Faculty of Education, Kütahya/Turkey }\end{array}$} \\
\hline Article Info & Abstract \\
\hline DOI:10.14812/cufej.2014.006 & $\begin{array}{l}\text { The purpose of this search is to evaluate the cleaning and hygiene in primary schools } \\
\text { according to the opinions of the students. For this purpose, } 201 \text { students from 6th and }\end{array}$ \\
\hline Article history: & 8th grades of a Primary School in AfyonkarahisarEmirdağ are considered as 'Study \\
\hline Received 18 December2012 & Universe'. 72 students are gathered as a sample from this universe with a cluster \\
\hline Revised $\quad 04$ December 2013 & sampling method and applied a questionnaire. In the analyses of the data, for the first \\
\hline Accepted 03 February 2014 & $\begin{array}{l}\text { sub problem, arithmetic mean and standard deviation; for the second sub problem, t- } \\
\text { text and one-way analysis of variance (ANOVA) is done. In the search, 6th and 8th }\end{array}$ \\
\hline $\begin{array}{l}\text { Keywords: } \\
\text { Primary school, } \\
\text { Cleaning, } \\
\text { Hygiene. }\end{array}$ & $\begin{array}{l}\text { grade students general average of their answers about the cleaning and hygiene in } \\
\text { primary schools is }(\bar{X}=2.53) \text {, that means their opinions are in 'enough' borders and } \\
\text { they have got an optimistic point of view. Also, according to the sexual parameter } \\
\text { there is not an important difference between schoolgirls [t }(68)=2.515, p>.05] \text { and } \\
\text { schoolboys }[\mathrm{t}(68)=2.579, \mathrm{p}>.05] \text { and according to their classes, the difference } \\
{[\mathrm{F}(21,48)=1.116, \mathrm{P}>.05] \text { is not so meaningful. }}\end{array}$ \\
\hline
\end{tabular}

\section{Introduction}

In Turkish National Education System, the new regulation, increasing the gradual mandatory education -also known as 4+4+4 in public- to 12 years, has been put into practice since 2012-2013 education period (ilköğretim ve Eğitim Kanunu ile Bazı Kanunlarda Değişiklik Yapılmasına Dair Kanun, 2012). In this new system, the children who turn 66 months old have been started to primary school since 30 September 2012, 2012-2013 education period. In Turkey, the primary education schools (primary and secondary schools) are accepted as mandatory basic education institutions which serve the students to grow and improve mentally and morally (ilköğretim ve Eğitim Kanunu, 1961; Taymaz, 1997), and its aims include" having the students gain necessary information and skills for their personal health". Within possibility, there has to be a medical personnel (a doctor, a nurse) in primary schools and this personnel has to deal with the students' health at school (ilköğretim Kurumları Yönetmeliği, 2003). 4-5 years of the childhood have been spent in the family environment since the birth. This is the period when the child first starts to socialize. This mission is undertaken by the education institutions from the age of 5 and an important part of the children's lives starts to be spent at schools (Şahin, 2000). However, the students coming to school have different cultural and social environments and socio-economic structures of these families are also different. Just as this situation affects the readingwriting skills of the students, it also leads differences in the readiness level of the students related to health and cleaning habits (Başar, 1999; Enç, 1978).

Primary school period is a great period in which the students, coming from different atmospheres, are not only educated but they are also gained the awareness of cleaning, hygiene (convenience to healthy), protecting and improving their health such as the use of the toilets, washing hands with soap,

*Author: drahmetyilmaz68@gmail.com 
bryshing teeth, keeping the clothes clean, dropping the rubbish into the bin, ventilating the classroom, keeping the desks and tables clean, healthy nutrition(Başar, 2003; Başaran, 1994; Öztürk, Dicle, Sarı \&Bektaş, 2004). In the primary schools, that the training of cleaning and awareness of hygiene is not only applied at schools but also implemented on the managers, teachers and parents by the pediatrists and the nurses within the scope of the programme of improving health will increase the awareness (Pressey\& Robinson, 1991; Thackaberry, 2001). When the school children are thought not to be careful enough with preventive health measures, it is certain that the school management, teachers and other staff have important duties primarily about this subject (Başar, 2003; Şahin, 2000; Yörükoğlu, 1986). Within this scope, the school managers are assigned to train the students about the cleaning and hygiene (Başaran, 1994; Ilköğretim Kurumları Yönetmeliği, 2003; Taymaz, 1997).

In educating the students healthily and obtaining a qualified manpower, school environmental health has an important place. School is a comprehensive concept; the topics like school building, its infrastructure, its drinking and running water, its garden, removing the garbage, toilets, heating, ventilating, lighting, size of the classes and windows are all within the school environment (Güler\&Çobanoğlu, 2001). In this respect, physical structures and garden arrangements of the schools have an important effect on the cleaning habits and hygiene awareness of the students (Çabuk, 2006; Oktay, 1997; Uludağ\&Odacı, 2010). Besides, the school gardens, corridors, classrooms, toilets and canteen are the places used by the students frequently. Cleaning of these places daily, weekly or annually will have the students gain the awareness of cleaning and hygiene which will have a positive effect on the health of the students (Başaran, 1994; Hull, 1990).

This research is important in terms of determining the level of cleaning and hygiene according to the view of the students at school, rising the students' awareness of cleaning and hygiene to the desired level, having them gain the habit of protecting and improving their health, removing the faults appearing during the practice, taking the necessary precaution related to this and thus forming the healthy education atmosphere at primary schools.

The problem related to this subject is that cleaning and hygiene of the primary schools are evaluated according to the views of the $6^{\text {th }}$ and $8^{\text {th }}$ grade students. In order to achieve this goal, answers for the following questions are searched.

1. What are the views of the $6^{\text {th }}$ and $8^{\text {th }}$ grade students about the cleaning and hygiene of their schools?

2. Are there crucial differences among the views of the $6^{\text {th }}$ and $8^{\text {th }}$ grade students about the cleaning and hygiene of their schools in terms of;

a) their gender?

b) their classes?

\section{Method}

\section{Research Design}

This research aiming to evaluate the cleaning and hygiene according to the views of the students is in survey model.

\section{Participants}

The research population is composed of the $6^{\text {th }}$ and $8^{\text {th }}$ gradestudents of the school in Emirdag district, Afyonkarahisar. Out of 201 students present in target population, only 72 students of B branches of all $6^{\text {th }}$ and $8^{\text {th }}$ grades are chosen as examples with "cluster sampling method" because of their convenience for the research. With this sampling method, not the units composing the universe but the clusters to which these units are tied have been handled and in practice not the units that have 
the equal probability of being chosen but the clusters have been chosen (Karasar, 2004; Ural \&Kılıç, 2005).

\section{Instrument}

The personal information section of the survey improved in the research is made up of 2 articles and the main part is made up of 25 articles. And the options of the survey are listed like "Strongly Disagree (1), Occasionally Agree (2), Mostly Agree (3) and Completely Agree (4)". In the survey, the score offset value is obtained by dividing the gap digit (3) into the number of options (4), (3/4=0.75). In the research, that the average is on the level of mostly agree, that is $(\bar{X}=2.50)$ and more, is accepted and interpreted as students opinions are "enough"

\section{Data Analysis}

The data's obtained from the surveys have been uploaded to the packaged software called "SPSS 13.0 for Windows (Statistical Package for Social Sciences)" and "Cronbach (Alpha)" coefficient calculated for the internal reliability of the survey has been found .803. The survey prepared for the works for validity and reliability is applied to the 30 students of another school which did not take part in the sampling every 20 days and "Pearson correlation coefficient" between the two application has been found $r=.710$ Arithmetic mean and standard deviation for the first sub problem and t-test and one-way analysis of variance for the second sub problem is applied. The significance level is considered $p<.05$ in all statistical operation.

\section{Results}

When the data's about the first sub problem of the research -"what are the opinions of the students of $6^{\text {th }}$ and $8^{\text {th }}$ grade about the cleaning and hygiene of their school?"- are evaluated. We have concluded that it is within the limit of "enough" and the students have a positive opinion in terms of cleaning and hygiene as the general average of the survey applied on the $6^{\text {th }}$ and $8^{\text {th }}$ grade students is $(\overline{\mathrm{X}}=2.53)$.

In the second sub problem; an answer for the question of "Are there crucial differences among the views of the $6^{\text {th }}$ and $8^{\text {th }}$ grade students about the cleaning and hygiene of their schools in terms of their gender?" is investigated and we have found out from the data's obtained that there is no crucial difference between the opinions of male and female students.

Again about the second sub problem; an answer for the question of "Are there crucial differences among the views of the $6^{\text {th }}$ and $8^{\text {th }}$ grade students about the cleaning and hygiene of their schools in terms of their classes?" is investigated and we have found out that there is no crucial difference between the opinions of the students of the different classes.

\section{Discussion, Conclusion \& Implementation}

When the whole data obtained from the research is evaluated, the students' opinions related to the cleaning and hygiene of their schools are within the limit of "enough" and we have concluded that the students have a positive opinion in terms of cleaning and hygiene about the investigated school as the general average of the survey results related to the cleaning and hygiene of the school is ( $\overline{\mathrm{X}}=2.53$ ).

The students are constantly informed about the protection methods from the contagious and epidemic diseases obtained from this research (A flu, jaundice, measles, chickenpox). That the attendance to the item $(\overline{\mathrm{X}}=1.88)$ is inadequate and in a research named "School Health In the Primary Schools In Suburbs" applied by Aytaç (1990) states the first five diseases found out after the medical examination respectively as otorhinolaryngologic disease (64.1\%), tooth diseases (49.9\%), skin diseases 
(21.1\%), respiratory tract illnesses (19.9\%), genital system diseases (18.7\%) shows that today the students are not still informed adequately about health protection in terms of the cleaning habit and hygiene awareness at schools.

The fact that the attendance to this research whose result states "there is sufficient place for the students to play in the garden $(\overline{\mathrm{X}}=2.62)$ " is enough does not match with the result of the research named "The Investigating The Effects Of Primary School Gardens On Child Development" applied by Özdemir\& Yılmaz (2009) which states "the school garden does not have enough place for play". Besides, the finding obtained from this research which states "the students are gained the habit of brushing teeth and washing hands" does not match with the finding of the research named "Determining The Health Conditions Of The School Children" applied by Öztürk, Dicle, Sarı \&Bektaş (2004) which states that $47.3 \%$ of the students brush their teeth 2 or 3 times a day. And also it can be said that the finding which says "the bathrooms of the school have liquid soap constantly $(\overline{\mathrm{X}}=2.81)$ " is not parallel with the negative statement of Yilmaz (2012a) and (2012b) who applied similar researches the results of which state "the bathrooms of the school have enough liquid soap".

However, in order to improve the cleaning and hygiene at schools;

Sample studies (like the cleanest classroom) can be done with the classroom teachers and the counselors in order to have the students gain the habit of keeping the school and the classrooms clean. When needed, the sample schools which won "White Flag" because of their being clean can be visited.

The students drink water from the taps at schools. These taps are generally in the school yards. Cooperation can be made with municipalities about the arrangements of the school gardens by the protocol signed within the project of "Okullar Hayat Olsun" (Milli Eğitim Bakanlığı, 2011; Özel Öğretim Kurumlarına Ait Standartlar Yönergesi, 2012).

The expert health personnel can organize informative panels, conferences, symposium for the students, teachers and parents about how to protect the students from the contagious and epidemic diseases (like a flu, jaundice, measles and chicken pox).

Providing liquid soap and paper towel in the bathrooms at school is important in terms of preventing the epidemic diseases and having the students gain the habit of cleaning and hygiene awareness.

Cooperation can be made with provincial/district director of national education and provincial/district health director in order to control the students' health regularly at schools regularly.

When the primary schools are considered to be the common places shared by all the students, it is necessary to keep first aid materials in the first aid cabinets in order to respond to any injuries.

In addition, according to the Primary School Regulations (2003) schools can employ a healthpersonnel. Within possibility, all primary schools can keep a healthpersonnel. A sustainable general health politics can be applied in order to respond to the needs of the students and control them constantly within the frame of the cooperation of Ministery of National Education and Ministrery of Health by considering the special conditions of the students at primary schools in Turkey (like prothesis, diabetes, using medical equipment an allergy diseases) 


\section{Illköğretim Okullarındaki Temizlik ve Hijyenin Öğrenci Görüşlerine Göre Değerlendirilmesi}

\begin{tabular}{|c|c|}
\hline${ }^{\mathrm{a}}$ Milli & $\begin{array}{l}\text { akanlığı, İ Eğitim Denetmeni, Afyonkarahisar/Turkey } \\
\text { ar Üniversitesi, Eğitim Fakültesi, Kütahya/Turkey }\end{array}$ \\
\hline Makale Bilgisi & Öz \\
\hline DOI:10.14812/cufej.2014.006 & $\begin{array}{l}\text { Bu araştırmanın amacı, ilköğretim okullarındaki temizlik ve hijyenin öğrenci görüşlerine } \\
\text { göre değerlendirilmesidir. Bu amaca yönelik Afyonkarahisar ili Emirdağ ilçesindeki bir }\end{array}$ \\
\hline Makale geçmişi: & ilköğretim okulunun 6.-8. sınıfları çalışma evreni olarak alınmıştır. Bu evrende bulunan \\
\hline Geliş $\quad 18$ Aralık 2012 & 201 öğrenciden "Küme Örnekleme Yöntemi" ile 6.-8. sınıflarındaki 72 öğrenci \\
\hline Düzeltme 04 Aralık 2013 & örnekleme alınarak anket uygulanmıştır. Verilerin çözümünde birinci alt problem için \\
\hline Kabul $\quad 03$ Şubat 2014 & $\begin{array}{l}\text { aritmetik ortalama ve standart sapma; ikinci alt problem için t-test ve tek yönlü } \\
\text { varyans analizi (ANOVA) yapılmıştır. Araştırmaya katılan öğrencilerin cinsiyetleri }\end{array}$ \\
\hline $\begin{array}{l}\text { Anahtar kelimeler: } \\
\text { illköğretim okulu, } \\
\text { Temizlik, } \\
\text { Hijyen. }\end{array}$ & $\begin{array}{l}\text { bakımından görüşleri değerlendirildiğinde kız öğrencilerin }[\mathrm{t}(68)=2.515, \mathrm{p}>.05] \text { ve erkek } \\
\text { öğrencilerin }[\mathrm{t}(68)=2.579, \mathrm{p}>.05] \text { görüşleri arasında anlamlı fark olmadığı ve yine } 6 .-8 \text {. } \\
\text { sınıflar bakımından da öğrencilerin görüşleri arasında }[\mathrm{F}(21,48)=1.116, p>.05] \text { anlamlı } \\
\text { farklııı olmadığı bulguları elde edilmiştir. Araştırmada; öğrencilerin anket maddelerine } \\
\text { verdikleri cevapların genel ortalaması ( } \bar{X}=2.53) \text { olduğundan görüşlerinin "yeterli" } \\
\text { sınırlar içerisinde kaldığı böylece } 6 .-8 \text {. sınıf öğrencilerinin ilköğretim okullarının temizlik } \\
\text { ve hijyenine ilişkin olumlu görüşe sahip oldukları sonucuna ulaşılmıştır. }\end{array}$ \\
\hline
\end{tabular}

\section{Giriş}

Türk Milli Eğitim Sisteminde “ilköğretim ve Eğitim Kanunu İle Bazı Kanunlarda Değişiklik Yapılmasına Dair Kanun" ile kamuoyunda 4+4+4 olarak bilinen ve zorunlu eğitimi 12 yıla çıkaran yeni düzenleme 2012-2013 eğitim öğretim yılından itibaren uygulamaya konulmuştur. Bu değişiklikle birlikte halen uygulanmakta olan 8 yıllık kesintisiz zorunlu eğitim yerine, 12 yıllık zorunlu, kademeli eğitim getirilerek 12 yıllık süre üç kademeye ayrılmıştır. Birinci kademe 4 yıl süreli ilkokul (1. 2. 3. ve 4. sınıf), ikinci kademe 4 yıl süreli ortaokul (5. 6. 7. ve 8. sınıf) ve üçüncü kademe 4 yıl süreli lise (9. 10. 11. ve 12. sınıf) olarak düzenlenmiştir. Bu sistemde ilköğretim okulları ilkokul ve ortaokul şeklinde düzenlenmiştir (illköğretim ve Eğitim Kanunu İle Bazı Kanunlarda Değişiklik Yapılmasına Dair Kanun, 2012).

Bu yeni sistemde 2012-2013 eğitim ve öğretim yılından itibaren 30 Eylül 2012 tarihi itibariyle 66. ayını dolduran çocuklar ilk defa ilkokula başlatılmıştır. Ayrıca gelişim yönünden yeterince hazır olduğu düşünülen 61-66 ay arasındaki çocuklar da velisinin istemesi halinde ilkokula kayıt yaptırma imkânı tanınmıştır. Türkiye'de ilköğretim okulları (ilkokul+ortaokul), öğrencilerin zihni ve ahlaki gelişmelerine ve yetişmelerine hizmet eden zorunlu temel eğitim ve öğretim kurumları olarak kabul edilmiş olup (Illköğretim ve Eğitim Kanunu, 1961; Taymaz, 1997), amaçları arasında; “öğrencilere, kişisel sağlığını korumak için gerekli bilgi ve beceri kazandırmak" ilkesi yer almaktadır. Yine imkân dahilinde ilköğretim okullarında sağlık personeli (doktor, hemşire) bulundurulabileceği ve bu personele okuldaki öğrencilerin sağlıklarıyla ilgilenmeleri yükümlülüğü getirilmiştir (illköğretim Kurumları Yönetmeliği, 2003). Ancak ilköğretim okullarında sağlık personeli görevlendirilmesine uygulamada pek rastlanmamaktadır.

*Yazar: drahmetyilmaz68@gmail.com 
Doğumdan itibaren çocukluk döneminin ilk 4-5 yaşı aile ortamı içinde geçmektedir. Bu dönem, çocuğun ilk sosyalleşmeye başladığı dönemdir. 5 yaşından itibaren ailenin bu görevini eğitim kurumları üzerine almakta ve çocukların yaşamlarının önemli bir kısmı artık okullarda geçmeye başlamaktadır. Böylece okul çağı çocuğun aile yuvasından çıkıp, dış dünyaya açıldığı, toplumsal çevreye karıştığı ve sosyalleşmenin artarak devam ettiği ortam olma özelliği taşımaktadır (Şahin, 2000). Ancak okula gelen öğrencilerin kültürel ve toplumsal çevreleri ile ailelerinin sosyo-ekonomik yapıları birbirinden farklıdır. Bu durum öğrencilerin okuma-yazma becerilerini etkilediği gibi sağlık ve temizlik alışkanlıklarıyla ilgili hazırbulunuşluk düzeylerinin de farklı olmasına neden olmaktadır (Başar, 1999; Enç, 1978).

Ilköğretim dönemi, farklı ortamlardan gelen öğrencilere öğretimlerinin yanı sıra tuvalet kullanma, ellerini sabunla yıkama, dişlerini fırçalama, elbiselerini temiz tutma, çöpleri çöp kutusuna atma, sınıfı havalandırma, sıra ve masaları temiz tutma, dengeli beslenme gibi (Başar, 2003; Başaran, 1994) temizlik eğitimi ve hijyen (sağlığa uygunluk) bilinci veren, sağlıklarını koruma ve geliştirme alışkanlıkları kazandırılan mükemmel bir dönemdir (Öztürk, Dicle, Sarı ve Bektaş, 2004). İlköğretim okullarında öğrencilere verilen bu temizlik eğitimi ve hijyen bilinci sadece okul ile sınırlı kalmayıp gerektiğinde çocuk doktorları, okul hemşireleri tarafından sağlık geliştirme programı çerçevesinde yönetici, öğretmen ve velilere kadar götürülmesi bu konudaki duyarlıı̆̆ı daha da arttırdığı muhakkaktır (Pressey ve Robinson, 1991; Thackaberry, 2001). Yine herkese açık olan sağılık sergileri veya yılık grip asısı programı gibi aktiviteler, kanser ve diyabet derneklerinin ve kalp akciğer dernekleri gibi gönüllü sağlık kuruluşlarının yapacağı faaliyetler okul ve çevre arasında iyi ilişkiler kurulmasına yardım eder (Thackaberry, 2001). Böylelikle okullarda temizlik eğitimi ve hijyen bilinci yalnızca belli derslerde, belli sürelerde yapılan etkinlik olmaktan çıkıp sağılık kuruluşları, veli, öğretmen ve okul yöneticilerinin de desteklediği süreç olma özelliği kazanacaktır (Başaran, 1994).

Ilköğretim okulları, öğrencilerin toplu olarak yaşadıkları ve etkileşim içinde oldukları yerler olduğundan bulaşıcı hastalıkların ortaya çıkması ve yaygınlaşması için oldukça elverişli bir ortam olma özelliği taşır. Özellikle ilköğretim çağındaki çocukların koruyucu sağlık önlemleri konusunda yeterince bilinçli ve özenli davranmadıkları düşünüldüğünde, bu konuda öncelikle okul yönetimine, öğretmenlere ve diğer okul çalışanlarına önemli görevler düştüğü muhakkaktır (Başar, 2003; Şahin, 2000; Yörükoğlu, 1986). Bu anlamda eğitim sistemi ilköğretim okullarını yönetmekle görevli müdürlere, öğrencilere temizlik eğitimi ve hijyen bilinci kazandırmaya yönelik bazı görevler yüklemiştir. Bunlar (Başaran, 1994; ilköğretim Kurumları Yönetmeliği, 2003; Taymaz, 1997):

- Öğrencilere okul ve çevresinde sağılıkı, güvenli bir eğitim-öğretim ortamı oluşturmak,

- Öğrencilerin sağlık muayenelerini ve gerekli aşılarını, periyodik olarak yaptırmak,

- Herhangi bir sosyal güvencesi olmayan öğrencilerin hastalanmaları halinde sağlık kuruluşlarına sevklerini yapmak,

- Ekonomik durumu yetersiz olan öğrencilerin ilaç giderlerinin Sosyal Yardımlaşma ve Dayanışma Vakfı tarafından karşılanmasını sağlamak,

- Okulun derslik, laboratuar, işlik, yemekhane, yatakhane gibi bölümlerinde ISI, ışık ve havalandırmanın sağlık şartlarına uygun olmasını sağlamak,

- Öğrencilerin kılık-kıyafetlerinin temiz ve düzenli olması için gerekli önlemleri almak,

- Öğrencilerin sağlıklı beslenebilmeleri için uygun sağlık koşulları oluşturmak,

- Okulda, ilk yardım dolabı yada ilk yardım çantası bulundurmak ve gerekli malzemeleri temin etmektir.

Öğrencilerin sağlıkı bir şekilde yetiştirilerek kaliteli insan gücü elde edilebilmesinde okul çevre sağlığı önemli bir yere sahiptir. Okul geniş kapsamlı bir kavramdır; okul binası, alt yapısı, içme ve kullanma suları, bahçesi, çöplerin uzaklaştırılması, tuvaletler, ısıtma, havalandırma, aydınlatma, sınıfların ve pencerelerin büyüklüğü gibi konular okul çevresi kapsamında değerlendirilebilir (Güler ve Çobanoğlu 2001). Bu bakımdan ilköğretim okullarının fiziki yapıları ve bahçe düzenlemeleri öğrencilerin temizlik alışkanlıkları ve hijyen bilinçleri üzerinde önemli etkisi vardır. Çünkü öğrencilere okulların fiziki yapısı 
bakımından uygun mekânsal konfor ve yeterli güneş ışığı sağlanamadığında, dersliklerde gelişigüzel renkler kullanıldığında, öğrencilerde fizyolojik ve psikolojik olumsuzluklar oluşabilmekte ve bu durum temizlik ve hijyen bilincinin oluşmasını olumsuz etkileyebilmektedir (Çabuk, 2006; Oktay, 1997; Uludağ ve Odacı, 2010).

Yine fiziki mekan olarak okullarda bulunan ve daha az kullanılan depo, kalorifer dairesi, arşiv gibi bölümler çeşitli mikroorganizmaların üremesi, haşerelerin çoğalması için uygun ortam sağlayan yerlerdir (Başar, 2003; Başaran, 1994). Bunun yanı sıra okul bahçesi, koridorlar, derslikler, tuvaletler ve kantin öğrenciler tarafından en çok kullanılan bölümlerdir. Okullarda gerek en çok kullanılan gerekse en az kullanılan bu tür bölümlerin temizliği özelliklerine göre günlük, haftalık ve yıllık periyotlarda düzenli olarak yapılması zaman zaman dezenfekte edilmesi öğrencilerin sağlığı üzerinde olumlu etki yapacak temizlik ve hijyen bilinci oluşmasına katkıda bulunacaktır (Başaran, 1994; Hull, 1990).

Ilköğretim okullarındaki temizlik alışkanlığı ve hijyen bilinci ile ilgili yapılan bazı benzer araştırmaların bulguları incelendiğinde;

Aytaç (1990) tarafından yapılan "Kırsal Alanda Illkokullarda Okul Sağlı̆ıı" adlı araştırmasında, yapılan fizik muayenede öğrencilerde rastlanan ilk 5 hastalığın sırasıyla, KBB (\% 64.1), diş hastalığı (\% 49.9), deri hastalığı (\% 21.1), solunum yolu hastalığı (\% 19.9), genital sistem hastalığı (\% 18.7) olduğu bulgularını elde etmiştir. Yine dışkıda parazit görülme sıklğının (\% 17.7) olduğu ve göz hastalıkları oranlarının da (\% $9,6)$ olduğu bulgusuna ulaşmıştır.

Öztürk vd. (2004) tarafından yapılan "Okul Dönemindeki Çocukların Sağılık Durumlarının Belirlenmesi" araştırmasında öğrencilerin \% 47.3'ünün dişlerini günde 2-3 kez fırçaladığı, öğrencilerin \% $78.1^{\prime}$ inin günde üç öğün yemek yediği, öğrencilerin \% 11,2'sinin okul kazası geçirdiği, öğrencilerin \% 10 'nunun 8 saatten az uyuduğu bulgusuna ulaşmışlardır.

Özdemir ve Yılmaz'ın (2009) yaptığı, "ilköğgretim Okulları Bahçelerinin Çocuk Gelişimi ve Sağlıklı Yaşamları Üzerine Etkilerinin İncelenmesi" araştırmasında, öğrencilerin büyük bir bölümünün (\% 78.2) oyun oynadığı okul bahçesinin ihtiyaçlarını karşılamadığı, yine bu öğrencilerin 537'sinin de okul bahçelerindeki yeşil alanın yetersiz olduğunu belirttikleri bulgusuna ulaşmışlardır.

Yılmaz (2012a) tarafından yapılan, “ilköğretim Okullarının Fiziksel Yapılarının Eğitim ve Öğretim Açısından Değerlendirilmesi" araştırmasında, okulun tuvaletlerinin öğrencilerin ihtiyaçlarını karşılamadığı ve okullardaki tuvaletlerin sayıca yetersiz olduğu bulgusuna ulaşmıştır.

Yılmaz (2012b) tarafından yapılan, "Yatılı Illköğretim Bölge Okulları Sorunlarının Öğrenci Algılarına Göre Değerlendirilmesi" adlı araştırmasında,okul ve yatakhanelerin yeterince temizlenmediği, öğrencilerin okullarında rahatlıkla banyo yapamadıkları ve okullarındaki tuvaletlerde sürekli sabun bulundurulmadığı ve ihtiyaçlarını karşılamadığı bulgusuna ulaşmıştır.

Bu araştırma; ilköğretim okullarındaki temizlik ve hijyenin öğrenci görüşlerine göre belirlenerek; öğrencilerde temizlik alışkanlığı ve hijyen bilincinin arzulanan hedeflere ulaştırılması, sağlıklarını koruma ve geliştirme alışkanlıkları kazandırılması, bu konuda ilköğretim okullarında uygulamada karşılaşılan aksaklıkların giderilmesi, kolaylaştıııı önlemlerin alınması böylelikle ilköğretim okullarında sağlıklı eğitim ve öğretim ortamı oluşturulmasına katkı sağlaması ve bu konuda araştırma boşluğunu doldurması bakımından önem taşımaktadır.

Buna bağlı olarak araştırmanın problemi, ilköğretim okullarındaki temizlik ve hijyenin 6.-8. sınıflarda bulunan öğrencilerin görüşlerine göre değerlendirilmesidir. Bu amaca ulaşmak için de aşağıdaki şu alt problemlere cevap aranmıştır.

1) 6.-8. sınıf öğrencilerinin ilköğretim okullarının temizlik ve hijyenine ilişkin görüşleri nelerdir?

2) 6.-8. sınıf öğrencilerinin ilköğretim okullarının temizlik ve hijyenine ilişkin görüşleri arasında; 
a) cinsiyetleri

b) sınıfları bakımından anlamlı fark var mıdır?

\section{Yöntem}

\section{Araştırma Modeli}

İlköğretim okullarındaki temizlik ve hijyenin öğrenci görüşlerine göre değerlendirilmesini amaçlayan bu araştırma tarama modelindedir.

\section{Katılımcılar}

Araştırmada mevcut durum ortaya konulacağından dolayı betimsel niteliktedir. Araştırma evrenini Afyonkarahisar'a bağlı Emirdağ ilçesinde bulunan bir ilköğretim okulunun 6.-8. sınıflarında bulunan öğrenciler oluşturmaktadır. Buna göre çalışma evrenini ve örneklemi oluşturan öğrenci sayıları aşağıda Tablo 1'de sunulmuştur.

Tablo 1.

Evren ve Örnekleme Giren Öğrenci Sayıları.

\begin{tabular}{lcccc}
\hline & \multicolumn{2}{c}{ Evren } & \multicolumn{2}{c}{ Örneklem } \\
\cline { 2 - 5 } Sınıflar & $\mathbf{N}$ & $\mathbf{\%}$ & $\mathbf{N}$ & $\%$ \\
\hline 6/A Şubesi & 19 & 100 & 0 & 0 \\
6/B Şubesi & 23 & 100 & 23 & 100 \\
6/C Şubesi & 21 & 100 & 0 & 0 \\
7/A Şubesi & 20 & 100 & 0 & 0 \\
7/B Şubesi & 20 & 100 & 20 & 100 \\
7/C Şubesi & 20 & 100 & 0 & 0 \\
8/A Şubesi & 25 & 100 & 0 & 0 \\
8/B Şubesi & 29 & 100 & 29 & 100 \\
8/C Şubesi & 24 & 100 & 0 & 0 \\
\hline Toplam & 201 & 100.0 & 72 & \\
\hline
\end{tabular}

Tablo 1'e göre çalışma evreninde bulunan 201 öğrenciden araştırmaya uygunluğu nedeniyle "Küme Örnekleme Yöntemi" ile 6.-8. sınıflarda bulunan şubelerden sadece B şubelerindeki 72 öğrenci örnekleme alınmıştır. Bu örnekleme yöntemi ile öncelikle evreni oluşturan birimler değil bu birimlerin bağı olduğu kümeler ele alınmış olup uygulamada eşit olasılıkla seçilme şansına sahip olan birimler değil kümeler seçilmiştir (Karasar, 2004; Ural ve Kılıç, 2005). Araştırmada uygulama yapılan ilköğretim okulundaki öğrenci sayıları Milli Eğitim Bakanlığı MEBBis (Milli Eğitim Bakanlığı Bilişim Sistemi) elektronik veri tabanından alınmıştır.

\section{Veri Toplama Aracı}

Araştırmada geliştirilen anketin kişisel bilgiler bölümü 2 maddeden, ana bölüm ise 25 maddeden oluşmaktadır. Anket maddeleri seçenekler "Hiç Katılmıyorum (1), Arasıra Katılıyorum (2), Çoğunlukla Katılıyorum (3) ve Tamamen Katılıyorum (4)" şeklinde sıralanmıştır. Ankette, puan aralık değeri; aralık sayısı (3), seçenek sayısına (4), (3/4=0.75) bölünerek şöyle tespit edilmiştir (Tablo 2).

Buna göre yapılan araştırmada; ortalamanın "çoğunlukla düzeyi"nde yani $(\bar{X}=2.50)$ ve üzeri olması öğrencilerin görüşlerinin "yeterli" olduğu şeklinde kabul edilmiş ve yorumlanmıştır. Geçerlik ve güvenirlik çalışması için hazırlanan anket; örnekleme girmeyen Emirdağ ilçesindeki başka bir ilköğretim okulundaki toplam 30 öğrenciye 20 gün ara ile uygulanmış olup iki uygulama arasındaki "Pearson Korelasyon Katsayısı" $r=.710$ bulunmuştur. Anketlerden elde edilen veriler "SPSS 13.0 for Windows 
(Statistical PackageForSocialSciences)" paket programına yüklenmiş ve anketin iç güvenirliği için hesaplanan "Cronbach (Alpha)" katsayısı .803 olarak bulunmuştur.

Tablo 2.

Anket Puan Tablosu ve Değerleri.

\begin{tabular}{lccl}
\hline \multicolumn{1}{c}{ Seçenekler } & Puan & Alt-Üst Sınır & Puana Karşılık Gelen Yorum \\
\hline Hiç katılmıyorum & 1.00 & $1.00-1.74$ & Hiç düzeyinde \\
Arasıra katılıyorum & 2.00 & $1.75-2.49$ & Arasıra düzeyinde \\
Çoğunlukla katılıyorum & 3.00 & $2.50-3.24$ & Çoğunlukla düzeyinde \\
Tamamen katılıyorum & 4.00 & $3.25-4.00$ & Tamamen düzeyinde \\
\hline
\end{tabular}

\section{Verilerin Toplanmas}

Veriler 2010-2011 bahar yarıyılında, çalışma evreninde bulunan ilköğretim okulunun 6.-8. sınıflarının sadece B şubelerindeki öğrencilere anket (kişisel bilgiler bölümünde 2, ana bölüm de 25 madde olan) uygulanarak toplanmıştır.

\section{Verilerin Analizi}

Araştırma ile ilgili literatür taraması yapıldıktan sonra, ilköğretim okullarında görevli yönetici, öğretmen, rehber öğretmen ve öğrencilerin ve uzman görüşleri de alınarak hazırlanan anketler, Emirdağ Kaymakamlığından uygulama izni alındıktan sonra Emirdağ ilçesinde bulunan bir ilköğretim okulunun B şubesindeki 72 öğrenciye uygulanmıştır. Ancak öğrencilere uygulanan bu anketlerden geriye dönenler arasında yapılan incelemelerde 2 anketin ana bölümünün öğrenciler tarafından eksik doldurulduğunun anlaşılması üzerine geçersiz kabul edilmiştir. Buna göre geçerli olarak kabul edilen ve işleme alınan anket sayısı (72-2=70) olmuştur. Araştırmada öğrencilerin görüşlerini yansıtan veriler "SPSS 13.0" paket programına kodlanarak kaydedilmiştir. Birinci alt problem için aritmetik ortalama ve standart sapma; ikinci alt problem için t-test ve tek yönlü varyans analizi (ANOVA) yapılmıştır. Yapılan tüm istatistiksel işlemlerde anlamlıık düzeyi $P<.05$ alınmıştır.

Ayrıca uygulamaya katılan öğrencilerin anket maddelerine verdikleri cevaplara göre değişkenler arasındaki korelasyonu hesaplamak için birbiri ile ilişkili olan ve aynı boyutu ölçen değişkenlerin gruplandırılmasına yönelik faktör analizi yapılmıştır. Anket maddeleriyle ilgili toplam varyansın faktörlerine ilişkin korelasyon matrisi sonuçları aşağıdaki Tablo 3’te sunulmuştur.

Tablo 3.

Toplam VaryanstaFaktörlere Ilişkin Korelasyon Matrisi.

\begin{tabular}{lcc}
\hline Faktörler & $\begin{array}{c}\text { Varyans } \\
\%\end{array}$ & $\begin{array}{c}\text { Birikimli Varyans } \\
\%\end{array}$ \\
\hline 1. Faktör & 8.734 & 08.734 \\
2. Faktör & 8.392 & 17.127 \\
3. Faktör & 7.528 & 24.655 \\
4. Faktör & 7.435 & 32.090 \\
5. Faktör & 7.426 & 39.515 \\
6. Faktör & 7.286 & 46.801 \\
7. Faktör & 7.178 & 53.979 \\
8. Faktör & 6.224 & 60.203 \\
9. Faktör & 5.758 & 65.961 \\
\hline
\end{tabular}

Tablo 3’e göre uygulanan anketteki 25 maddeye ilişkin ölçeğin 9 faktörlü (boyutlu) olduğu görülmektedir. Bu 9 faktör toplam varyansın \% 65.961'ini açıklamaktadır. Buna göre; birinci faktör toplam varyansın \% 8.734'ünü, ikinci faktör toplam varyansın \% 8.392'sini, üçüncü faktör toplam 
varyansın \% 7.528'ini, dördüncü faktör toplam varyansın \% 7.435'ini, beşinci faktör toplam varyansın \% 7.426'sını, altıncı faktör toplam varyansın \% 7.286'sını, yedinci faktör toplam varyansın \% 7.178'ini, sekizinci faktör toplam varyansın \% 6.224'ünü ve dokuzuncu faktör toplam varyansın \% 5.758'ini açıklamaktadır.

\section{Bulgular}

\section{Kişisel Bilgilere Ait Bulgular}

Emirdağ ilçesinde bulunan ve örnekleme alınan ilköğretim okulunun 6.-8. sınıflarında bulunan öğrencilerin sınıflarına göre sayıları ve cinsiyetlerine ilişkin kişisel bilgilerine ait bulgular Tablo. 4'te sunulmuştur.

Tablo 4.

Örnekleme Giren Öğrencilerin Sınıflarına Göre Cinsiyet Dağılımları.

\begin{tabular}{|c|c|c|c|c|}
\hline \multicolumn{5}{|c|}{ Öğrencilerin Sınıfları } \\
\hline Cinsiyet & 6/B & 7/B & $8 / B$ & Toplam \\
\hline $\mathrm{K} ı \mathrm{Z}$ & 16 & 14 & 20 & 50 \\
\hline Erkek & 7 & 6 & 9 & 22 \\
\hline Toplam & 23 & 20 & 29 & 72 \\
\hline
\end{tabular}

Tablo 4'e göre kız öğrencilerin sayısı 50 (\% 69) ve erkek öğrencilerin sayısı ise 22'dir (\% 31). Örneklemde bulunan toplam öğrenci sayısı ise 72 'dir.

\section{Birinci Alt Probleme ilişkin Bulgular}

Araştırmanın birinci alt problemi olan "6.-8. sınıf öğrencilerinin ilköğretim okullarının temizlik ve hijyenine ilişkin görüşleri nelerdir?” sorusu ile ilgili bulgular Tablo 5'te sunulmuştur.

Tablo 5’e göre 6.-8. sınıf öğrencilerinin ilköğretim okullarının temizlik ve hijyenine ilişkin görüşlerine ait bulgulara göre; okul tuvaletlerinde sürekli sıvı sabun bulunmaktadır ( $\bar{X}=2.81)$, okulda öğrencilerin içtiği suların kontrolleri sürekli yaptırılmaktadır $(\overline{\mathrm{X}}=2.60)$, yağışı havalarda okulun içi çamur olmaması için gerekli tedbirler alınmaktadır $(\bar{X}=2.60)$, okulun uygun yerlerinde yeterince çöp kovası bulunmaktadır $(\bar{X}=2.61)$, derslikler teneffüslerde sürekli havalandırılmaktadır $(\bar{X}=2.72)$, öğrenciler elbiselerini temiz tutma alışkanlığı kazanmıştır ( $\overline{\mathrm{X}}=2.90)$, okulun içi ve dışı sürekli boya badana yapılmaktadır $(\overline{\mathrm{X}}=2.62)$, okul bahçesinde öğrencilerin oturabileceği yerler bulunmaktadır $(\overline{\mathrm{X}}=2.87)$, derslikler yeterince ısınmaktadır $(\overline{\mathrm{X}}=2.57)$, bahçede öğrencilerin oyun oynayabileceği yeterince oyun alanı vardır $(\overline{\mathrm{X}}=2.62)$, okul haşerelere (bit, pire, sinek gibi) karşı belli aralıklarla ilaçlanmaktadır $(\bar{X}=2.75)$, öğrencilere el yıkama ve diş fırçalama gibi alışkanlıklar kazandırımıştır ( $\bar{X}=2.65)$, okulda sağlıkla ilgili belirli gün ve haftalar amacına uygun olarak kutlanmaktadır ( $\overline{\mathrm{X}}=3.12$ ) maddelerinin ortalaması $(\overline{\mathrm{X}}=2.50)$ ve üzerinde olduğu için öğrencilerin bu maddelerle ilgili görüşlerinin "yeterli" olduğu bulgusuna ulaşılmıştır.

Yine öğrencilerin görüşlerine göre; okul derslikleri sürekli temizdir ( $\bar{X}=2.35)$, okulda öğrencilerin rahatlıkla su içebileceği musluklar mevcuttur $(\bar{X}=2.45)$, okulun kapı, pencerelerinin ve ders araç gereçlerinin sürekli temizliği yapılmaktadır $(\bar{X}=2.42$ ), bulaşıcı ve salgın hastalıklardan (A gribi, sarılık, kızamık, suçiçeği gibi) korunma yöntemleriyle ilgili öğrenciler sürekli bilgilendirilmektedir $(\bar{X}=1.88)$, tuvaletlerde sürekli kağıt havlu bulunmaktadır $(\overline{\mathrm{X}}=2.11)$, okulda çöpler zamanında boşaltılmaktadır $(\bar{X}=2.37)$, okul bahçesi sürekli temiz tutulmaktadır $(\bar{X}=2.44)$, öğrenciler sıra ve duvarların karalanmaması için duyarlı davranmaktadır ( $\bar{X}=2.42)$, öğrencilerin düzenli sağlık kontrolleri yapılmaktadır $(\bar{X}=2.41)$, okuldaki ilkyardım dolabında acil durumlar için sürekli malzeme bulunmaktadır $(\overline{\mathrm{X}}=2.32)$, öğrencilerin kalorifer yada yakacak deposuna girmemesi için gerekli tedbirler alınmıştır $(\overline{\mathrm{X}}=2.48)$, okulda özürlüler için 
gerekli kolaylaştııı tedbirler alınmıştır $(\overline{\mathrm{X}}=2.10)$ maddelerine katılım $(\overline{\mathrm{X}}=2.50)$ altında olduğundan "yetersiz" olduğu bulgusuna ulaşılmıştır.

Tablo 5.

ilköğretim Okullarında Temizlik ve Hijyenin Değerlendirilmesine ilişkin Öğrenci Görüşlerine Ait Aritmetik Ortalama ve Standart Sapmaları.

\begin{tabular}{|c|c|c|c|c|}
\hline & Anket Maddeleri & $\mathbf{N}$ & $\overline{\mathbf{X}}$ & Ss \\
\hline 1. & Okul tuvaletlerinde sürekli sıvı sabun bulunmaktadır & 70 & 2.81 & 1.10 \\
\hline 2. & Okul derslikleri sürekli temizdir & 70 & 2.35 & 1.04 \\
\hline 3. & Okulda öğrencilerin rahatıkla su içebileceği musluklar mevcuttur & 70 & 2.45 & 1.17 \\
\hline 4. & Okulda öğrencilerin içtiği suların kontrolleri sürekli yaptırılmaktadır & 70 & 2.60 & 1.04 \\
\hline 5. & $\begin{array}{l}\text { Yağışı havalarda okulun içi çamur olmaması için gerekli tedbirler } \\
\text { alınmaktadır }\end{array}$ & 70 & 2.60 & 1.12 \\
\hline 6. & $\begin{array}{l}\text { Okulun kapı, pencerelerinin ve ders/araç gereçlerinin sürekli temizliği } \\
\text { yapılmaktadır }\end{array}$ & 70 & 2.42 & 1.11 \\
\hline 7. & Okulun uygun yerlerinde yeterince çöp kovası bulunmaktadır & 70 & 2.61 & 1.03 \\
\hline 8. & Derslikler teneffüslerde sürekli havalandırılmaktadır & 70 & 2.72 & 1.06 \\
\hline 9. & $\begin{array}{l}\text { Bulaşıcı ve salgın hastalıklardan (A gribi, sarılık, kızamık, suçiçeği gibi) } \\
\text { korunma yöntemleriyle ilgili öğrenciler sürekli bilgilendirilmektedir }\end{array}$ & 70 & 1.88 & 1.08 \\
\hline 10. & Tuvaletlerde sürekli kâğıt havlu bulunmaktadır & 70 & 2.11 & 1.15 \\
\hline 11. & Öğrenciler elbiselerini temiz tutma alışkanlığı kazanmıştır & 70 & 2.90 & .95 \\
\hline 12. & Okulda çöpler zamanında boşaltılmaktadır & 70 & 2.37 & 1.14 \\
\hline 13. & Okul bahçesi sürekli temiz tutulmaktadır & 70 & 2.44 & 1.16 \\
\hline 14. & Okulun içi ve dışı sürekli boya badana yapılmaktadır & 70 & 2.62 & 1.10 \\
\hline 15. & Öğrenciler sıra ve duvarların karalanmaması için duyarlı davranmaktadır & 70 & 2.42 & 1.13 \\
\hline 16. & Öğrencilerin düzenli sağlık kontrolleri yapılmaktadır & 70 & 2.41 & 1.13 \\
\hline 17. & $\begin{array}{l}\text { Okuldaki ilkyardım dolabında acil durumlar için sürekli malzeme } \\
\text { bulunmaktadır }\end{array}$ & 70 & 2.32 & 1.07 \\
\hline 18. & $\begin{array}{l}\text { Öğrencilerin kalorifer yada yakacak deposuna girmemesi için gerekli } \\
\text { tedbirler alınmıştır }\end{array}$ & 70 & 2.48 & .86 \\
\hline 19. & Okul bahçesinde öğrencilerin oturabileceği yerler bulunmaktadır & 70 & 2.87 & .75 \\
\hline 20. & Derslikler yeterince ısınmaktadır & 70 & 2.57 & 1.08 \\
\hline 21. & Bahçede öğrencilerin oyun oynayabileceği yeterince oyun alanı vardır & 70 & 2.62 & 1.13 \\
\hline 22. & $\begin{array}{l}\text { Okul haşerelere (bit, pire, sinek gibi) karşı belli aralıklarla } \\
\text { ilaçlanmaktadır }\end{array}$ & 70 & 2.75 & 1.01 \\
\hline 23. & Öğrencilere el yıkama ve diş fırçalama gibi alışkanlıklar kazandırıımıştır & 70 & 2.65 & 1.15 \\
\hline 24. & Okulda özürlüler için gerekli kolaylaştırıcı tedbirler alınmıştır & 70 & 2.10 & 1.81 \\
\hline 25. & $\begin{array}{l}\text { Okulda sağlıkla ilgili belirli gün ve haftalar amacına uygun olarak } \\
\text { kutlanmaktadır }\end{array}$ & 70 & 3.12 & 1.02 \\
\hline & Genel aritmetik ortalama & & \multicolumn{2}{|c|}{$(\overline{\mathrm{X}}=2.53)$} \\
\hline
\end{tabular}

\section{íkinci Alt Probleme ilişkin Bulgular}

İkinci alt problemde; "6.-8. sınıf öğrencilerinin ilköğretim okullarının temizlik ve hijyenine ilişkin görüşleri arasında cinsiyetleri bakımından anlamlı fark var mıdır?" sorusuna cevap aranmış olup bulgular aşağıda Tablo. 6'da sunulmuştur.

Tablo 6'ya göre 6.-8. sınıf öğrencilerinin ilköğretim okullarının temizlik ve hijyenine ilişkin görüşlerinin cinsiyet değişkenine göre fark olup olmadığını belirlemek amacıyla yapılan anketin t-test sonuçlarına göre sadece 7. maddede yer alan "okulun uygun yerlerinde yeterince çöp kovası bulunmaktadır" maddesinde $\mathrm{k} ı \mathrm{z}[\mathrm{t}(68)=2.428, \mathrm{p}<.05]$ ve erkek öğrencilerin $[\mathrm{t}(68)=3.047, \mathrm{p}<.05]$ görüşleri arasında 
anlamlı fark olduğu, geriye kalan diğer maddelerde ise öğrencilerin görüşleri arasında anlamlı farklılık olmadığı bulgusuna ulaşılmıştır.

Tablo 6.

Ilköğretim Okullarında Temizlik ve Hijyenin Değerlendirilmesiyle Ilgili Maddelere Verilen Cevaplara Göre Öğrencilerin Cinsiyetleri Bakımından t-Test Sonuçları.

\begin{tabular}{|c|c|c|c|c|c|c|c|}
\hline Madde & Cinsiyet & $\mathbf{N}$ & $\overline{\mathbf{X}}$ & Ss & t-değer & Sd & $\mathbf{P}$ \\
\hline \multirow{2}{*}{1} & $\mathrm{~K} ı \mathrm{Z}$ & 49 & 2.653 & 1.164 & 1.896 & 68 & .055 \\
\hline & Erkek & 21 & 2.579 & .217 & & & \\
\hline \multirow{2}{*}{2} & $\mathrm{~K} ı \mathrm{z}$ & 49 & 2.408 & 1.039 & .618 & 68 & .538 \\
\hline & Erkek & 21 & 2.238 & 1.091 & & & \\
\hline \multirow{2}{*}{3} & $\mathrm{~K} ı \mathrm{Z}$ & 49 & 2.530 & 1.156 & .797 & 68 & .428 \\
\hline & Erkek & 21 & 2.285 & 1.230 & & & \\
\hline \multirow{2}{*}{4} & $\mathrm{~K} ı \mathrm{z}$ & 49 & 2.632 & .993 & .398 & 68 & .692 \\
\hline & Erkek & 21 & 2.523 & 1.167 & & & \\
\hline \multirow{2}{*}{5} & $\mathrm{~K} ı \mathrm{Z}$ & 49 & 2.551 & 1.155 & 2.551 & 68 & .581 \\
\hline & Erkek & 21 & 2.579 & 1.055 & & & \\
\hline \multirow{2}{*}{6} & $\mathrm{~K} ı \mathrm{Z}$ & 49 & 2.428 & 1.118 & .000 & 68 & 1.00 \\
\hline & Erkek & 21 & 2.428 & 1.121 & & & \\
\hline \multirow{2}{*}{7} & $\mathrm{~K} ı \mathrm{Z}$ & 49 & 2.428 & 1.060 & 2.357 & 68 & $.021^{*}$ \\
\hline & Erkek & 21 & 3.047 & .864 & & & \\
\hline \multirow{2}{*}{8} & $\mathrm{~K} ı \mathrm{Z}$ & 49 & 2.857 & 1.040 & 1.563 & 68 & .123 \\
\hline & Erkek & 21 & 2.428 & 1.075 & & & \\
\hline \multirow{2}{*}{9} & $\mathrm{~K} ı \mathrm{Z}$ & 49 & 1.775 & .963 & 1.306 & 68 & .196 \\
\hline & Erkek & 21 & 2.142 & 1.314 & & & \\
\hline \multirow{2}{*}{10} & $\mathrm{~K} ı \mathrm{Z}$ & 49 & 2.061 & 1.197 & 1.225 & 68 & .225 \\
\hline & Erkek & 21 & 2.428 & 1.028 & & & \\
\hline \multirow{2}{*}{11} & $\mathrm{~K} ı \mathrm{Z}$ & 49 & 2.938 & .875 & .519 & 68 & .606 \\
\hline & Erkek & 21 & 2.809 & 1.123 & & & \\
\hline \multirow{2}{*}{12} & $\mathrm{~K} ı \mathrm{Z}$ & 49 & 2.326 & 1.143 & .928 & 68 & .620 \\
\hline & Erkek & 21 & 2.476 & 1.167 & & & \\
\hline \multirow{2}{*}{13} & $\mathrm{~K} ı \mathrm{z}$ & 49 & 2.387 & 1.055 & .603 & 68 & .549 \\
\hline & Erkek & 21 & 2.571 & 1.325 & & & \\
\hline \multirow{2}{*}{14} & $\mathrm{~K} ı \mathrm{Z}$ & 49 & 2.673 & 1.106 & .516 & 68 & .607 \\
\hline & Erkek & 21 & 2.523 & 1.123 & & & \\
\hline \multirow{2}{*}{15} & Kız & 49 & 2.326 & 1.161 & 1.150 & 68 & .254 \\
\hline & Erkek & 21 & 2.666 & 1.064 & & & \\
\hline \multirow{2}{*}{16} & $\mathrm{~K} ı \mathrm{Z}$ & 49 & 2.387 & 1.151 & .297 & 68 & .768 \\
\hline & Erkek & 21 & 2.476 & 1.123 & & & \\
\hline \multirow{2}{*}{17} & $\mathrm{~K} ı \mathrm{Z}$ & 49 & 2.326 & 1.087 & .024 & 68 & .981 \\
\hline & Erkek & 21 & 2.333 & 1.064 & & & \\
\hline \multirow{2}{*}{18} & $\mathrm{~K} ı \mathrm{Z}$ & 49 & 2.489 & .868 & .060 & 68 & .952 \\
\hline & Erkek & 21 & 2.476 & .872 & & & \\
\hline 19 & $\mathrm{~K} ı \mathrm{Z}$ & 49 & 2.898 & .770 & .444 & 68 & .659 \\
\hline 19 & Erkek & 21 & 2.809 & .749 & & & \\
\hline 20 & $\mathrm{~K} ı \mathrm{z}$ & 49 & 2.612 & 1.114 & .478 & 68 & .634 \\
\hline 20 & Erkek & 21 & 2.476 & 1.030 & & & \\
\hline 21 & $\mathrm{~K} ı \mathrm{Z}$ & 49 & 2.612 & 1.169 & .183 & 68 & .855 \\
\hline 21 & Erkek & 21 & 2.666 & 1.064 & & & \\
\hline & $\mathrm{K} ı \mathrm{z}$ & 49 & 2.775 & 1.005 & .230 & 68 & .819 \\
\hline 22 & Erkek & 21 & 2.714 & 1.055 & & & \\
\hline & $\mathrm{K} ı \mathrm{z}$ & 49 & 2.591 & 1.171 & .721 & 68 & .473 \\
\hline 23 & Erkek & 21 & 2.809 & 1.123 & & & \\
\hline & $\mathrm{K} ı \mathrm{Z}$ & 49 & 2.061 & 1.179 & .417 & 68 & .678 \\
\hline 24 & Erkek & 21 & 2.190 & 1.209 & & & \\
\hline 25 & $\mathrm{~K} ı \mathrm{Z}$ & 49 & 3.163 & 1.007 & .432 & 68 & .667 \\
\hline$\angle 5$ & Erkek & 21 & 3.047 & 1.071 & & & \\
\hline Genel & $\mathrm{K} ı \mathrm{Z}$ & & 2.515 & .268 & .949 & 68 & .346 \\
\hline Genel & Erkek & & 2.579 & .271 & & & \\
\hline & & & & & & & $p>.05$ \\
\hline
\end{tabular}

*p<.05 olduğunu göstermektedir. 
Ancak 7. maddedeki kız ve erkek öğrencilerin görüşleri arasındaki bu farklılık anket maddelerin tümü üzerinde anlamlı fark oluşturmamaktadır. Çünkü tüm anket maddelerine verilen cevaplar incelendiğinde $\mathrm{kIz}[\mathrm{t}(68)=2.515, \mathrm{p}>.05]$ ve erkek öğrencilerin $[\mathrm{t}(68)=2.579, \mathrm{p}>.05]$ görüşleri arasında anlamlı fark olmadığı bulgusuna ulaşılmıştır. Ancak kız öğrencilerin görüşleri ( $\bar{X}=2.515)$ erkek öğrencilerin görüşlerinden ( $\overline{\mathrm{X}}=2.579)$ daha olumsuz olduğu anlaşılmaktadır.

Yine ikinci alt problemle ilgili olarak;6.-8. sınıf öğrencilerinin ilköğretim okullarının temizlik ve hijyenine ilişkin görüşleri arasında sınıfları bakımından anlamlı fark var mıdır? sorusuna cevap aranmıştır.

Tablo 7.

Illköğretim 6.-8. Sınıf Öğrencilerinin IIlköğretim Okullarının Temizlik ve Hijyenine Ilişkin Sınıfları Bakımından Genel Aritmetik Ortalama ve Standart Sapmaları.

\begin{tabular}{lccc}
\hline & $\mathbf{N}$ & $\overline{\mathbf{X}}$ & Ss \\
\hline 6. sinıflar & 21 & 2.409 & .267 \\
7. sinıflar & 20 & 2.672 & .205 \\
8. sinıflar & 29 & 2.531 & .234 \\
\hline Genel & 70 & 2.534 & .254 \\
\hline
\end{tabular}

Tablo. 7'ye göre 6. sınıfların ortalaması ( $\bar{X}=2.409)$, 7. sınıfların ortalaması $(\bar{X}=2.672)$ ve 8. sınıfların ortalaması ( $\overline{\mathrm{X}}=2.531)$ dir. Buna göre 6. sınıfların ortalaması yetersiz sınırlar içinde kalsa da 7 . ve 8 . sınıfların ortalaması yeterli sınırlar $(\overline{\mathrm{X}}=2.50)$ içerisinde olduğu anlaşılmaktadır.

Buna göre araştırmadan elde edilen bulgular bir bütün olarak değerlendirildiğinde; 6.-8. sınıf öğrencilerinin ilköğretim okullarının temizlik ve hijyenine ilişkin anket maddelerine verdikleri cevapların genel ortalaması ( $\overline{\mathrm{X}}=2.534)$ olduğundan öğrencilerin ilköğretim okullarının temizlik ve hijyenine ilişkin görüşlerinin "yeterli" sınırlar içerisinde kaldığı ve öğrencilerin ilköğretim okullarının temizlik ve hijyeniyle ilgili olumlu görüşe -çoğunlukla katılıyorum düzeyinde- sahip oldukları anlaşılmaktadır. Sınıflarla ilgili yapılan tek yönlü varyans analizi sonuçları Tablo 8'de sunulmuştur.

Tablo 8.

Ilköğretim 6.-8. Sınıf Öğrencilerinin IIköğretim Okullarının Temizlik ve Hijyenine ilişkin Sınıfları BakımındanVaryans Analizi (ANOVA) Sonuçları.

\begin{tabular}{lccccc}
\hline \multicolumn{1}{c}{$\begin{array}{l}\text { Varyans } \\
\text { Kaynağı }\end{array}$} & $\begin{array}{c}\text { Kareler } \\
\text { Toplamı }\end{array}$ & Sd & $\begin{array}{c}\text { Kareler } \\
\text { Ortalaması }\end{array}$ & $\mathbf{F}$ & $\mathbf{P}$ \\
\hline Gruplararası & 16.102 & 21 & .767 & & \\
Grup içi & 32.983 & 48 & .687 & 1.116 & .365 \\
Genel & 49.086 & 69 & - & & \\
\hline
\end{tabular}

Tablo 8'e göre 6.-8. sınıf öğrencilerinin ilköğretim okullarının temizlik ve hijyenine ilişkin görüşleri bir bütün olarak değerlendirildiğinde; 6.-8. sınıf öğrencilerinin görüşleri arasında sınıfları bakımından $[F(21,48)=1.116, P>.05]$ tek yönlü varyans analizi sonuçlarına göre .05 düzeyinde anlamlı farklılık olmadığı bulgusuna ulaşılmıştır. Bu bulgu 6.-8. sınıf öğrencilerinin ilköğretim okullarının temizlik ve hijyenine ilişkin görüşlerinin benzer olduğunu göstermektedir.

\section{Sonuç, Tartışma ve Öneriler}

Bu araştırmadan elde edilen" bulaşıcı ve salgın hastalıklardan (A gribi, sarılık, kızamık, suçiçeği gibi) korunma yöntemleriyle ilgili öğrenciler sürekli bilgilendirilmektedir ( $\bar{X}=1.88)$," maddesine katılımın yetersiz olmasıyla; Aytaç (1990) tarafından yapılan "Kırsal Alanda illkokullarda Okul Sağlığı" adlı araştırmasındaki, yapılan fizik muayenede öğrencilerde rastlanan ilk 5 hastalığın sırasıyla, KBB (\% 64.1), diş hastalığı (\% 49.9), deri hastalığı (\% 21.1), solunum yolu hastalığı (\% 19.9), genital sistem hastalığı (\% 
18.7) olduğu bulgularının paralel olması günümüzde de öğrencilerin eğitim kurumlarında yeterince temizlik alışkanlığı ve hijyen bilinci bakımından sağlıklarını korumalarına yönelik bilgilendirilmedikleri sorununun kısmen de olsa devam ettiğini göstermektedir.

$\mathrm{Bu}$ araştırmadan elde edilen "bahçede öğrencilerin oyun oynayabileceği yeterince oyun alanı vardır $(\bar{X}=2.62)$ " bulgusuna katılımın yeterli olmasıyla, Özdemir ve Yılmaz (2009) tarafından yapılan, "ilköğretim Okulları Bahçelerinin Çocuk Gelişimi ve Sağlıklı Yaşam Üzerine Etkilerinin İncelenmesi" adlı araştırmasından elde ettikleri, öğrencilerin büyük bir bölümünün (\% 78.2) görüş belirttiği oyun alanı için okul bahçesinin ihtiyacı karşılamadığı bulgusu ile uyuşmamaktadır. Ayrıca yine bu araştırmadan elde edilen "öğrencilere el yıkama ve diş fırçalama gibi alışkanlıklar kazandırılmıştır ( $\bar{X}=2.65)$ " bulgusuyla Öztürk vd. (2004) tarafından yapılan "Okul Dönemindeki Çocukların Sağlık Durumlarının Belirlenmesi" adlı araştırmasından elde ettikleri öğrencilerin \% 47.3'ünün dişlerini günde 2-3 kez fırçaladığı bulgusuyla da uyuşmamaktadır. Yine bu araştırmadaki "okul tuvaletlerinde sürekli sıvı sabun bulundurulduğu $(\bar{X}=2.81)$ " bulgusu ile Yılmaz'ın (2012a) "ilköğretim Okullarının Fiziksel Yapılarının Eğitim ve Öğretim Açısından Değerlendirilmesi" ve (2012b) "Yatılı Illköğretim Bölge Okulları Sorunlarının Öğrenci Algılarına Göre Değerlendirilmesi" adıı benzer araştırmasından elde ettiği "okullardaki tuvaletlerde sürekli sabun bulundurulduğu" maddesine öğrencilerin olumsuz görüş bildirmeleri ile de paralel olmadığı söylenebilir.

Buna göre araştırmadan elde edilen tüm bulgular değerlendirildiğinde; 6.-8. sınıf öğrencilerinin ilköğretim okullarının temizlik ve hijyenine yönelik öğrencilerin anket maddelerine verdikleri cevapların genel ortalaması ( $\overline{\mathrm{X}}=2.53$ ) olduğundan öğrencilerin ilköğretim okullarının temizlik ve hijyenine ilişkin görüşlerinin "yeterli" sınırlar içerisinde kaldığı ve araştırma yapılan ilköğretim okulu ile ilgili olarak öğrencilerin temizlik ve hijyen bakımından olumlu görüşe sahip oldukları sonucuna ulaşılmıştır.

Ancak ilköğretim okulunda öğrencilerde temizlik alıskanlığı ve hijyen bilincinin kazandırılması ve daha da geliştirilebilmesi için;

Illköğretim okullarında öğrenciler aynı derslik içinde eğitim öğretim gördüğü göz önünde bulundurulduğunda bu ortamların sürekli temiz tutulması için gerekli önlemler alınabilir. Bu önlemler gerektiğinde okulun kapı, pencere ve ders araç gereçlerinin "Eğitim Kurumları Temizlik Rehberi" doğrultusunda günlük, haftalık ve aylık periyotlarda temizlemek suretiyle yapılabilir. Burada okul müdürlüğünün sorumluluğu oldukça fazladır. Yine gerektiğinde okul-aile birliği aracıllı̆ıyla yardımcı hizmetli de tutulması yoluna gidilebilir. Ayrıca öğrencilerde okul ve bölümlerini temiz tutma davranışı kazandırmak için rehber öğretmenler ve sınıf öğretmenleri iş birliği içinde örnek çalışmalar (en temiz sınıf seçimi gibi) yapabilir. Gerektiğinde yakın çevrede temizliği nedeniyle "Beyaz Bayrak" (belirli ölçütlere göre yapılan değerlendirme sonucunda temiz olduğu belirlenen okullara belli süreliğine verilen bayrak) almış olan örnek okullar da ziyaret edilebilir. Bunun yanı sıra sosyal etkinlikler kapsamında kurulan kulüp çalışmaları çerçevesinde temizlik kulüpleri kurularak bu kapsamda "toplum hizmeti" çalışmalarına ağırlık verilebilir.

Illköğretim okullarında öğrenciler şehir suyuna bağlı musluklardan su içmektedir. Bu musluklar genellikle okul bahçesinde bulunmaktadır. Hava şartlarından ve kullanılan malzemeden dolayı musluklar da aşınmalar ve kirlenmeler olabilmektedir. Bu nedenle musluklar öğrencilerin her türlü hava şartlarında rahatlıkla yararlanabileceği konumda düzenlenmeli ve temizliğine de ayrıca dikkat edilmelidir. Yine tedbir olarak su kesintileri için en az okulun bir günlük su ihtiyacını karşılayacak büyüklükte su deposu veya tankı bulundurularak periyodik olarak (6 ayda) temizlikleri kontrol edilmelidir. (Özel Öğretim Kurumlarına Ait Standartlar Yönergesi, 2012). Yine bahçe düzenlemeleriyle ilgili musluk yerlerinin tespiti, bahçenin yeşillendirilmesi, oyun bölümleri ayrılması, dinlenme yerleri yapılması, çöp kutusu yerlerinin sağlık şartlarına uygun olarak belirlenmesi için gerektiğinde Milli Eğitim Bakanlığı ve diğer kurumlar arasında (2011) imzalanan protokol gereği "Okullar Hayat Olsun Projesi" çerçevesinde belediyelerle iş birliğine gidilebilir. 
İlköğretim okullarındaki öğrencilerin bulaşıcı ve salgın hastalıklardan (A gribi, sarılık, kızamık, suçiçeği gibi) nasıl korunacakları ile ilgili sürekli bilgilendirilme yapılması koruyucu sağlık bakımından önemlidir. Bu konuda belli dönemlerde uzman sağlık personeli okula davet edilerek öğrenci, öğretmen ve velilere yönelik bilgilendirici panel, konferans, sempozyum düzenlenebilir, broşür dağıtılabilir ve gerektiğinde yerel basından da faydalanılma yoluna gidilebilir.

İlköğretim okullarında tuvaletlerde sürekli sıvı sabun, kağıt havlu bulundurulması, salgın hastalıkların önlenmesi ve öğrencilere temizlik alışkanlığı ve hijyen bilinci kazandırılması bakımından önemlidir. Bu konuda Milli Eğitim Bakanlığı okullara doğrudan ödenek aktarabileceği gibi okul-aile birliğinden de imkan dahilinde gerekli maddi destek sağlanabilir.

İlköğretim okullarında öğrencilerin düzenli sağıı kontrollerinin (KBB, cilt, diş, göz vb.) yapılması için il/ilçe milli eğitim müdürlüğü ve il/ilçe sağlık müdürlüğü işbirliğine gidebilir. Yine öğrencilerin sağlık kontrol ve tedavi bilgileri e-okul sisteminden (öğrencilerin bilgilerinin elektronik olarak internet üzerinden işlenen kişisel bilgiler modülü) öğrencilerin kişisel sayfasına işlenebilir. Bu durum gerektiğinde diğer öğrenimlerini de (ortaöğretim, üniversite) kapsayacak şekilde devam ettirilebilir.

İlköğretim okulları öğrencilerin toplu olarak yaşadıkları yerler olduğu göz önünde bulundurulduğunda herhangi bir düşme, yaralanma halinde basit ilk tıbbi müdahale yapılabilmesi için ilkyardım dolaplarında sürekli ilkyardım malzemesi bulundurulması gerekliliği ortaya çıkmaktadır. Bu konuda gerektiğinde il/ilçe sağlık müdürlüklerinden, okul-aile birliğinden, eczanelerden yada gönüllü velilerden maddi destek sağlanabilir.

Ayrıca Illköğretim Kurumları Yönetmeliğine (2003) göre ilköğretim okullarında sağlık personeli bulundurulabileceği hükmü getirilmiştir. Bu uygulamada pek görülmese de İmkan dahilindeki ilköğretim okullarında sağlık personeli bulundurulmalı bu da mümkün değilse aynı eğitim bölgesinde (birbirine yakın 5-10 ilköğretim okulu bir eğitim bölgesidir) yer alan merkezi bir okulda çocuk doktoru, okul hemşiresi görevlendirilerek diğer okullara da hizmet verecek şekilde düzenleme yapılması yoluna gidilebilir.

Türkiye'de ilköğretim okulları mecburi eğitim ve öğretim kurumları olarak kabul edildiğinden bu yaş grubundaki öğrencilerin özel durumları (protez, şeker hastalığı, tıbbi cihaz kullanma, alerji hastalıkları gibi) göz önünde bulundurularak gerektiğinde Milli Eğitim Bakanlığı ve Sağlık Bakanlığı işbirliği çerçevesinde bu tür öğrencilerin sürekli kontrol altında bulundurulmalarına, ihtiyaçlarının karşılanmalarına ve destek olmaya yönelik sürdürülebilir genel sağlık politikası uygulamaya konulabilir. Çünkü sağııklı çocukların sağlıklı gelecek ve sağlıklı nesiller olduğu unutulmamalıdır.

\section{Kaynakça}

Aytaç, N. (1990). Kırsal alanda ilkokullarda okul sağlığı. Unpublished master's thesis, University of Çukurova, Adana.

Başar, H. (1999). Sınıf yönetimi. İstanbul: Milli Eğitim Bakanlığı Yayınları.

Başar, M. A. (2003). "ilköğretim kurumlarının olanakları. Unpublished doctoral dissertation, University of Ankara, Ankara.

Başaran, İ. E. (1994). Eğitim yönetimi. Ankara: Kadıoğlu Matbaası.

Çabuk, G. (2006). Illköğretim binalarının renk açısından değerlendirilmesi. Unpublished master's thesis, University of Çukurova, Adana.

Enç, M. (1978). Ruh sağı̆̆ı bilgisi. İstanbul: İnkılap ve Aka Basımevi. 
Güler, Ç. \& Çobanoğlu, Z. (2001). Çevre sağlığı eğitici el kitabı.Ankara: TC. Sağıık Bakanlığı Yayınları.

Hull, J.(1990). Classromskillsteacherguide.London: David Fulton Publication.

İlköğretim ve Eğitim Kanunu. (1961). Resmi gazete. 12/01/1961 tarih ve 10705 sayılı.

İlköğretim Kurumları Yönetmeliği. (2003). Resmi gazete.27/08/2003 tarih ve 25212 sayılı.

Illköğretim ve Eğitim Kanunu İle Bazı Kanunlarda Değişiklik Yapılmasına Dair Kanun. (2012).Resmi gazete.30/03/2012 tarih ve 6287 sayılı Kanun.

Karasar, N. (2004). Bilimsel araştırma yöntemi. Ankara: Nobel Yayın Dağıtım.

Milli Eğitim Bakanlığı.(2011). Okullar Hayat Olsun Projesi. MEB, Orman Su İşleri Bakanlığı, Türkiye Belediyeler Birliği, Gönüllü Katılımcılar ve Belediyeler arasında imzalanan 13 Aralık 2011 tarihli protokol.

Oktay, A. (1997). Çocuk ve okul. Ankara: Başbakanlık Basımevi.

Özdemir, A. \& Yılmaz, O. (2009). İlköğretim okulları bahçelerinin çocuk gelişimi ve sağlıklı yaşam üzerine etkilerinin incelenmesi. Milli Ĕgitim Dergisi, 37 (181), 121-130.

Özel Öğretim Kurumlarına Ait Standartlar Yönergesi. (2012). MEB (Özel Öğretim Kurumları) 17/08/2012 tarih ve 8108 sayılı yazıları ekinde yer alan.

Öztürk, M.C., Dicle, A., Sarı, H. Y.\& Bektaş, M.(2004). Okul dönemindeki çocukların sağlık durumlarının belirlenmesi. Milli Eğitim Dergisi, 32 (163), 156-167.

Pressey, S. L.\& Robinson P. F.(1991). Psikoloji ve yeni eğitim II. Ankara: MEB Yayınları.

Şahin, F. (2000). Okul sağlığı. Gazi Üniversitesi Tıp Fakültesi Çocuk Sağlığı ve Hastalıkları Ana Bilim Dalı Dergisi, 9 (6), 210-212.

Taymaz, A. H.(1997). Uygulamalı okul yönetimi. Ankara: AÜ. Eğitim Bilimleri Fakültesi Yayınları, Yayın No:180.

Thackaberry, J. (2001) Whocaresforthehealth of yourschool? Independent School, 60 (4), 94-98.

Uludağ, Z. \& Odacı, H. (2010). Eğitim-öğretim faaliyetlerinde fiziksel mekan. Milli Eğitim Dergisi,(153-

154), 18-36.

Ural, A. \& Kılıç, İ. (2005). Bilimsel araştırma süreci ve spss ile veri analizi.Ankara: Detay Yayınları.

Yılmaz, A. (2012a). ilköğretim okullarının fiziksel yapılarının eğitim ve öğretim açısından değerlendirilmesi. Balıkesir Üniversitesi Sosyal Bilimler Enstitüsü Dergisi, 15(28), 77-107.

Yılmaz, A. (2012b). Yatılı ilköğretim bölge okulları sorunlarının öğrenci algılarına göre değerlendirilmesi. Gaziantep Üniversitesi Sosyal Bilimler Dergisi, 11(3), 659-679.

Yörükoğlu, A. (1986). Çocuk ruh sağlığı. Ankara: Doğuş Matbaası. 